\title{
Surgical Pearl: A Novel Technique of Ingrown Nail Splinting
}

\author{
Muhammed Mukhtar ${ }^{1, *}$ \\ ${ }^{1}$ Mukhtar Skin Centre, Katihar Medical College Road, Katihar, India \\ "Corresponding author: MD, Consultant Dermatologist, Mukhtar Skin Centre, Katihar Medical College Road, 854105, Katihar, India. Email: drmmukhtar20@gmail.com
}

Received 2020 May 06; Accepted 2020 May 12.

Keywords: Ingrown Toenail, Polytube, Nail Splinting, Firm, Bevel, Small, Nail Canal, Hyponychium, Slit, Split

\section{Dear Editor,}

Ingrown toenail is an intermittent painful inflammation of the lateral nail unit of the great toe. Nail care habits and footwear are common contributory factors at a young age. Ingrown nail comprises about 20 percent of foot issues and is often treated moderately with simple, nonsurgical palliative measures. One of them is the utilization of polytube splint beneath the ingrown nail edge to isolate it from the nail canal. Polytube nail splinting promptly relieves the discomfort and has a low recurrence rate (1). However, conventional nail splinting technique, in which a long, longitudinally incised (slitted), soft, flexible IV set polytube is used, is a painful and time-taking procedure (25 ). Here I propose a novel technique for nail splinting of moderate to severe ingrown toenail using a little, firm, bisected (splitted), sloped polytube without local anesthesia and instrumentation. For a more straight-forward method for polytube nail splinting, a firm polytube from the container of a mouthwash bottle with an inner diameter of 2 $\mathrm{mm}$ is chosen. A segment of 4 to $5 \mathrm{~mm}$ length (about half the length of the lateral nail canal) is cut and longitudinally sliced in two identical parts by a shaving blade (Figure $1 \mathrm{~A}$ ). After this, one of its ends is beveled using a shaving blade for easier incorporation in the nail canal (Figure $1 \mathrm{~B}$ ). Under aseptic conditions, without local anesthesia and any instruments, the polytube is installed into the nail canal through the hyponychium from the slant end. This region is used for attachment to evade obstruction at the distal-most part of the nail canal due to inflammation and granuloma at the site (Figure $1 \mathrm{C}$ ). On reaching up to the distal part of the nail canal, some resistance is felt. By then, the tube is controlled inwards to place the tube in the nail canal. Thereafter, hemostasis is achieved, and the tube is fixed with cyanoacrylate glue alongside the neighboring tissue. (Figure 1D). To secure the position of the polytube in the canal, a twig of cotton can be put over the site before the use of the glue. In my experience, the patients treated with this technique felt a quick relief from pain and were able to do their routine work without any discomfort. The patients were put on oral antitibiotics and anti-inflammatory drugs along with topical antibiotics for 1 week postoperatively. In case of severe infections and inflammations, these treatments were given 1 week before the procedure. The patients must be followed up at fortnightly intervals for 12 weeks. Wrap up is done if the tube gets dislodged during the follow-up period. This method of nail splinting has been performed for 3 patients. All of them were relieved, and no recurrence was encountered during the follow-up period.

In conclusion, nail splinting with a circumferentially bisected small, firm, beveled polytube is a novel and unrivaled elective technique of noninvasive polytube bracing for the ingrown toenail. Local sedation and instrumentation are not required. This technique is easy, straightforward, and hardly takes 2 to 3 minutes for placing the polytube in the nail canal.

\section{Footnotes}

Conflict of Interests: The author declared no conflict of interest.

Funding/Support: There was no funding/support.

\section{References}

1. Mayeaux EJ, Carter C, Murphy TE. Ingrown Toenail Management. Am Fam Physician. 2019;100(3):158-64. [PubMed: 31361106].

2. Khunger N, Kandhari R. Ingrown toenails. Indian J Dermatol Venereol Leprol. 2012;78(3):279-89. doi: 10.4103/0378-6323.95442. [PubMed: 22565427].

3. Schulte KW, Neumann NJ, Ruzicka T. Surgical pearl: nail splinting by flexible tube-a new noninvasive treatment for ingrown toenails. J Am Acad Dermatol. 1998;39(4 Pt 1):629-30. doi: 10.1016/s01909622(98)70013-1. [PubMed: 9777771].

4. Kim YJ, Ko JH, Choi KC, Lee CG, Lim KJ. Nail-splinting technique for ingrown nails: the therapeutic effects and the proper removal time of the splint. Dermatol Surg. 2003;29(7):745-8. doi: 10.1046/j.15244725.2003.29182.x. [PubMed: 12828699].

5. Taheri A, Mansoori P, Alinia H, Lewallen R, Feldman SR. A conservative method to gutter splint ingrown toenails. JAMA Dermatol. 2014;150(12):1359-60. doi: 10.1001/jamadermatol.2014.1757. [PubMed: 25188750]. 

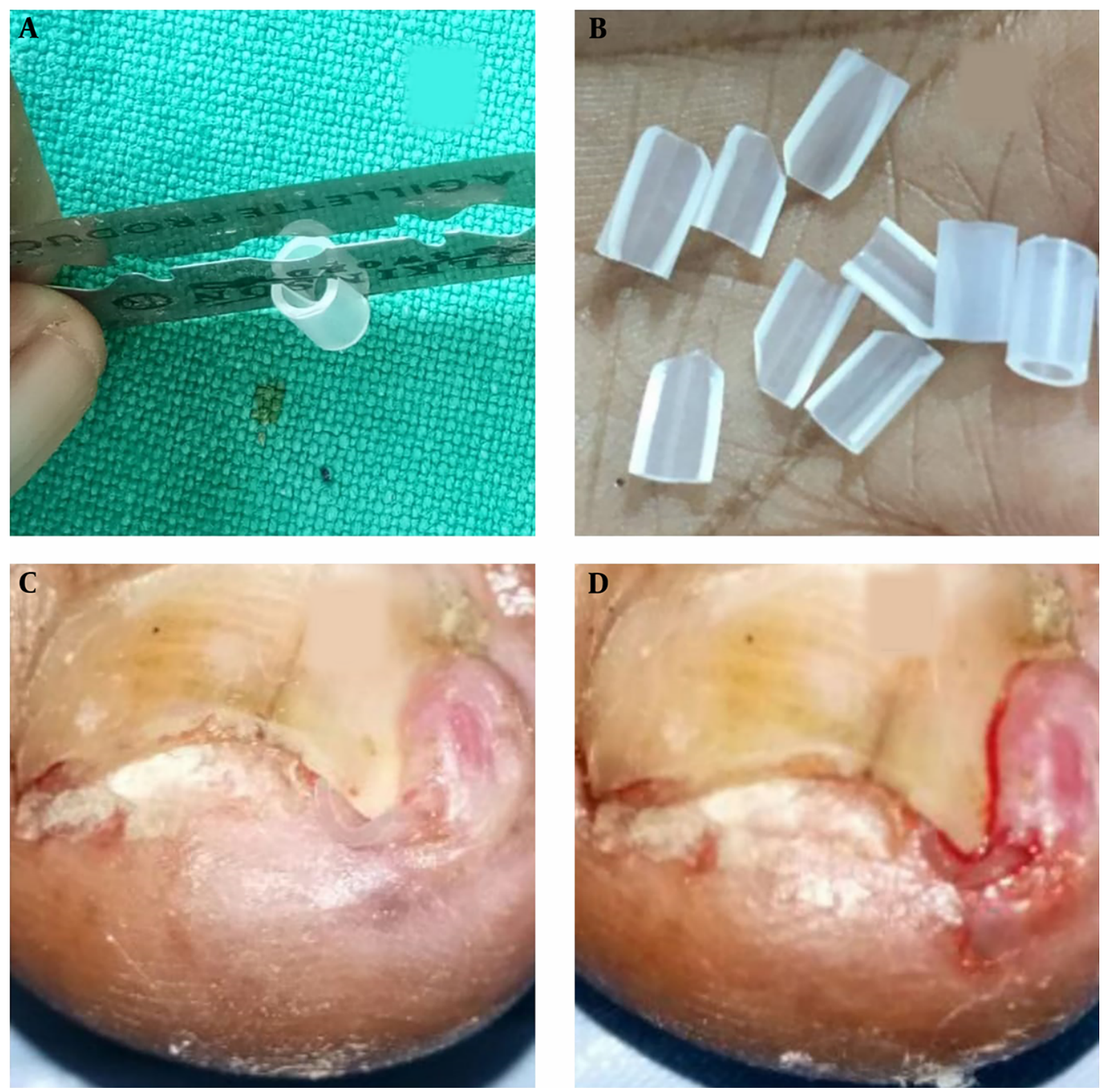

Figure 1. (A) A small polytube is being split. (B) Beveled polytube before the splinting. (C) The polytube is being placed through hyponychium in the nail canal. (D) The polytube is placed in the canal to splint ingrown nail. 